\title{
REGIONAL MAPPING AND PALAEOMAGNETIC AND GLACIOLOGICAL INVESTIGATIONS IN THE SCORESBY SUND REGION, CENTRAL EAST GREENLAND
}

\author{
Niels Henriksen
}

The fifth season of the five-year mapping programme in the Scoresby Sund region was carried out during July and August. A tent base-camp was established at the head of Fønfjord at the entrance to Hjørnedal (see fig. 5). The base served as an operation centre for three helicopters and one motor cutter and throughout the season a regular connection between the base and Mesters Vig airport was maintained with a small fixed-wing aircraft. The expedition numbered 44 persons comprising 14 two-man geological parties and supporting personnel. Ten parties mapped in the crystalline complex around the fjords Vestfjord, Fønfjord and Gåsefjord. One party mapped the western part of the Tertiary basalt area and one party made palaeomagnetic profiles in the basalts. Geochronological investigations in the crystalline areas were carried out by one party and another party undertook glaciological studies of some of the major glaciers in the western part of the region.

Approximately $6000 \mathrm{~km}^{2}$ were mapped in the Caledonian crystalline complex and about $3500 \mathrm{~km}^{2}$ of Tertiary Basalt were investigated. After five seasons' mapping the field work between $70^{\circ} 00^{\prime}$ and $72^{\circ} 00^{\prime}$ is completed and the Survey's Scoresby Sund project concluded.

\section{The crystalline complex}

The area mapped in 1972 is the southward continuation of the area mapped in 1970 and the geological composition of the two areas is very similar. The 1972 area lies between latitudes $70^{\circ} 00^{\prime} \mathrm{N}$ and $70^{\circ} 40^{\prime} \mathrm{N}$.

Part of the crystalline area of this year, the inner part of Gaseland and the adjacent nunatak area, has been mapped previously by Wenk (1961). Wenk distinguishes an autochthonous basement with a superimposed cover sequence exposed beneath a westwards thrust sequence of allochthonous schists and gneisses. He considered the parautochthonous cover sequence to represent the basal part of the Eleonore Bay Group, the late Precambrian deposits of the Caledonian geosyncline.

In the inner Scoresby Sund region mapped by GGU it has been possible to distinguish the following main units among the crystalline rocks: (1) a pre-Caledonian basement reworked by Caledonian events; (2) two supracrustal sequences the Charcot Land sequence and the Krummedal sequence; (3) migmatites in which the paleosome is similar to rocks occurring in the Krummedal supracrustal sequence; (4) syn- to post-kinematic intermediate to acid intrusions mainly confined to the migmatite region (Henriksen \& Higgins, 1970; 1971). 


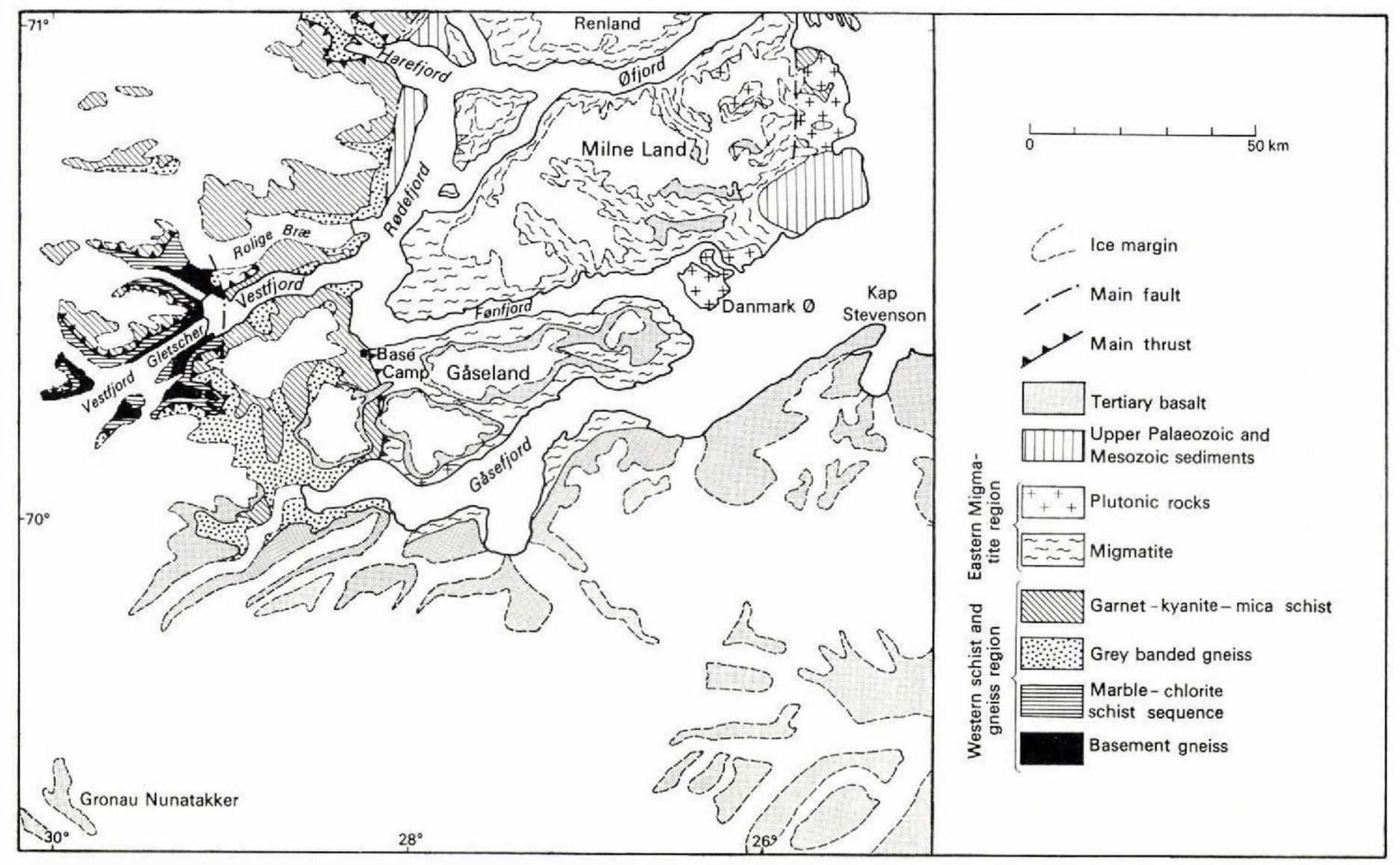

Fig. 5. Geological sketch map of part of the Scoresby Sund region, East Greenland, investigated in 1972 showing the localities mentioned in the article by Henriksen. 
The crystalline complex mapped in 1972 can be divided into; (1) a western schist and gneiss region incorporating a tectonic window with a basement and a superimposed supracrustal sequence; (2) an eastern migmatite region (see fig. 5). In the western region kyanite is a common metamorphic mineral, whereas the eastern region is characterised by sillimanite. The boundary between these two regions is a major fault-thrust zone, trending approximately north-south and following Rødefjord.

The western region was mapped by J. D. Friderichsen (GGU), L. Jemelin (Univ. of Lausanne) and A. Phillips and C. J. Stillman (Univ. of Dublin). The eastern migmatite region was mapped by K. Bucher-Nurminen and M. Fumasoli (Eidg. Techn. Hochschule, Zürich), J. C. Escher (GGU) and G. Sawatzki (Univ. of Geneva). N. Henriksen and A. K. Higgins (GGU) participated in the mapping in both the eastern and the western parts of the region.

The western region represents a part of the western boundary zone of the Caledonian fold belt in East Greenland. It includes an autochthonous infracrustal basement with a low metamorphic supracrustal cover sequence. At the base of this cover sequence occurs a thin impersistent psephitic level, previously recognised by Wenk (1961). The main part of the cover sequence, which can be several hundred metres thick, consists of flat-lying calcareous rocks with bands and schlieren of chloritic schists. Several of these schist bands can be shown to represent thin thrust slices of strongly tectonised basement. The bulk of the cover sequence may in places have been thrust over the basement.

A westward-directed major thrust unit comprising a lower phyllonitic gneiss complex, a thick complex of grey banded gneiss with amphibolites and an upper garnet-kyanite-mica schist complex is superimposed on the calcareous cover rocks. The phyllonitic gneiss complex, which was considered by Wenk to form a part of a cover sequence, is now interpreted as representing reworked basement rocks, which are thrust over the calcareous cover rocks. Evidence for this new interpretation was obtained by A. Phillips and C. J. Stillman, who were able to demonstrate the existence of gradual transitions between basement rock types and phyllonitic gneisses in the lower part of the thrust sheet. A gradual transition is also found between the phyllonitic gneiss and the thick complex of grey banded gneiss above. Large enclaves of basement rocks have been found in this otherwise uniform gneiss complex. The higher garnet-kyanite-mica schist unit contains in many places bands of grey, banded biotite-hornblende gneisses with amphibolite bands. In many cases these two rock groups are intensely folded together and in other cases they are separated by minor thrust planes. The mica schists are interpreted as the southern continuation of the Krummedal supracrustal sequence. The grey banded gneisses could represent strongly reworked basement comparable to the upper parts of the basement rocks of the Flyvefjord infracrustal complex (Henriksen \& Higgins, 1969).

The eastern migmatite region on Milne Land, Gåseland and south of Gåse- 
fjord comprises mainly migmatitic gneisses and migmatite granite. The paleosome elements in the migmatites occur not only as small inclusions, but form often extensive bands and zones of pelitic and psammitic gneisses. Marble bands, which are widespread on the eastern part of Gåseland and on south-west Milne Land, form some of the few mappable lithological marker units in the migmatite region. Amphibolitic rock types occur abundantly as enclaves in the part of the migmatite region mapped in 1972, which in this respect is in contrast to the migmatite region previously mapped further north (Henriksen \& Higgins, 1970). Otherwise the elements in the migmatites of various parts of the region are very similar.

Migmatite granites form extensive areas in the migmatite region. The granites are variable ranging from porphyritic, coarse-grained, biotite-garnet-bearing types to fine-grained biotite granites. They are generally viewed as an extreme development of migmatite. Most of them are conformable with the general structures and have gradational boundaries to the surrounding migmatitic gneisses. Often they contain numerous inclusions and ghost-like remnants of the paleosome elements. Sheet-like garnet-bearing granitic bodies occur especially in the easternmost part of the migmatite region and here are also found a few thin sheets of an augen granitic rock similar to those known from Renland and northern Milne Land (Henriksen \& Higgins, 1970).

On Danmark $\emptyset$ and along the southern coast of Gåseland there occur two large intrusive, sheet-like bodies of a grey, hornblende-biotite quartz diorite sensu lato. Small, comagmatic, basic inclusions are common, and late pegmatite veining is conspicuous. The quartz diorite sensu lato is in general appearance and mode of occurrence similar to the hornblende-(pyroxene)-quartz monzodiorite described from Liverpool Land (Coe \& Cheeney, 1972).

Geochronological investigations were carried out by B. T. Hansen with the object of collecting material for radiometric age determinations from both the western gneiss and schist region and the eastern migmatite region. The laboratory investigations will be carried out at the Institut für Kristallographie und Petrographie, Eidg. Technische Hochschule in Zürich as a part of the age determination programme already in progress (Hansen, Steiger \& Henriksen, 1972).

\section{Tertiary basalts}

The Tertiary basalts to the south of Gassefjord and to the west of Kap Stevenson together with the basalts in the greater part of Gasseland were mapped by W. S. Watt (GGU) and Margrethe Watt. Thirty-seven basalt profiles were traversed in connection with the mapping.

From Kap Stevenson, where the base of the basalt lies below sea level, the basalt-basement boundary rises steadily westwards and northwards. The strike and dip of the basalts are extremely uniform with a strike direction parallel to the outer, southern coast of Gåsefjord $\left(c .060^{\circ}\right)$ and a uniform dip of just under $2^{\circ}$ to the south-east. 
A stratigraphic field division based mainly on the presence or absence of plagioclase phenocrysts allowed division into three mappable units.

A visit to Gronau Nunatakker, $75 \mathrm{~km} \mathrm{SSW}$ of the head of Gåsefjord, showed the same general basalt type as found at the higher part of the sequence in the Scoresby Sund region.

The whole of the western end of the basalt area is essentially unfaulted and in the vicinity of the bottom of Gåsefjord numerous dolerite dykes appear. They occur in three main directions, N-S, NW-SE and ENE-WSW cutting the basalts. There are also lamprophyric dykes in this region cutting the basalts.

Field magnetic investigations using a hand compass were continued as in previous years and gave a reversed magnetic direction for the greater part of the stratigraphic sequence.

\section{Palaeomagnetic investigations}

E. A. Hailwood (Univ. of Southampton) and R. Løvlie (Geophys. Inst. of Bergen) systematically collected a series of oriented samples of the Tertiary basalts from a composite profile totalling approximately 2500 metres vertical thickness. The sampling was carried out with the use of a portable drill which provided cores of $2.5 \mathrm{~cm}$ in diameter. The composite profile involved sampling from four sections and the total profile represents nearly the total exposed basalt sequence in the Scoresby Sund region.

In addition to the core sampling the polarity of the magnetic field of various basalt levels was investigated using a portable fluxgate magnetometer. This work indicated that the majority of the flows have a reverse polarity, which is in accordance with the observations obtained by Watt \& Watt (1971) based on handcompass measurements.

\section{Glaciology}

O. B. Olesen (GGU) and N. Reeh (Danmarks Tekniske Højskole) began in 1968 a survey of the period variations in movement and production of calf ice of the major outlet-glaciers from the Inland Ice in the Scoresby Sund fjord complex (Olesen \& Reeh, 1969). This survey was continued in 1972 by the same geologists, and comprised investigations of the glaciers at the head of Vestfjord, Rolige Bræ and the northernmost of the glaciers at the head of Harefjord.

At Vestfjord Gletscher daily theodolite observations were made and a photogrammetric survey was executed at the beginning, middle and at the end of the observation period. A preliminary evalutation of the theodolite observations indicates the maximum movement at the front of the Vestfjord Gletscher to be about $9 \mathrm{~m} / 24 \mathrm{~h}$. The mean advance at the front is between 6 and $7 \mathrm{~m} / 24 \mathrm{~h}$ and corresponds to a production of about $3.5 \mathrm{~km}^{3} / \mathrm{year}$.

At the other glaciers only photogrammetric surveys were undertaken and this material has not yet been analysed. 


\section{References}

Coe, K. \& Cheeney, R. F. 1972: Preliminary results of mapping in Liverpool Land, East Greenland. Rapp. Grønlands geol. Unders. 48, 7-20.

Hansen, B. T., Steiger, R. H. \& Henriksen, N. 1972: The geochronology of the Scoresby Sund area. Rapp. Grønlands geol. Unders. 48, 105-107.

Henriksen, N. \& Higgins, A. K. 1969: Preliminary results of mapping in the crystalline complex around Nordvestfjord, Scoresby Sund, East Greenland. Rapp. Grønlands geol. Unders. 21, 5-20.

Henriksen, N. \& Higgins, A. K. 1970: Preliminary results of mapping in the crystalline complex of Renland, the southern Stauning Alper and south-west Liverpool Land, Scoresby Sund, East Greenland. Rapp. Grønlands geol. Unders. 30, 5-17.

Henriksen, N. \& Higgins, A. K. 1971: Preliminary results of mapping in the crystalline complex around Rypefjord and Rødefjord, and on northern Milne Land, Scoresby Sund, East Greenland. Rapp. Grønlands geol. Unders. 37, 5-18.

Olesen, O. B. \& Reeh, N. 1969: Preliminary report on glacier observations in Nordvestfjord, East Greenland. Rapp. Grønlands geol. Unders. 21, 41-53.

Watt, W. S. \& Watt, M. 1971: Preliminary report of the mapping of the basalts of parts of Milne Land and Gåseland. Rapp. Grønlands geol. Unders. 37, 42-50.

Wenk, E. 1961: On the crystalline basement and the basal part of the pre-Cambrian Eleonore Bay Group in the southwestern part of Scoresby Sund. Meddr Grønland 168, 1, 54 pp.

\section{SAMPLING FOR OIL SOURCE ROCK ANALYSIS, SCORESBY SUND REGION, CENTRAL EAST GREENLAND}

\section{N. B. H. Stevens and Katharina Perch-Nielsen}

From the 12th to 25 th of July outcrops of bituminous shales and limestones at four localities were visited by the authors. Three of the outcrops, at Fleming Fjord opposite Wegener Halv $\varnothing$, at Nathorst Fjord and at Edderfugledal were of Myalina Limestone of the Triassic Solfaldsdal Member. The fourth locality in the Schuchert Flod area near the western edge of the sedimentary basin involved the Upper Permian Posidonia Shale Member.

The main purpose of the field work was for Stevens, as the Survey's consultant, to get acquainted with the geology of the main rock types in the field, mainly with respect to environments of deposition and also to discover indications or proofs of the migration of hydrocarbons. Perch-Nielsen being conversant with the geology from previous seasons mapping acted as field guide. Samples were coilected for analysis to increase the information already obtained from samples collected by the Survey during previous mapping.

In a fault zone near the outcropping Posidonia Shale, the presence of $\mathrm{H}_{2} \mathrm{~S}$ was noted which is most probably related to the bituminous intercalations found within that member. One of the collected samples may contain traces of migrated 